\title{
ANUÊ JACI: POLÍTICA EXTERNA E POVOS INDÍGENAS DIANTE DA INFLEXÃO CONSERVADORA E DO BOLSONARISMO
}

César Santos ${ }^{1}$

RESUMO: Às vésperas do bicentenário da Independência do Brasil em relação a Portugal (1822-2022), a ascensão de Jair Messias Bolsonaro à Presidência da República desafia o povo brasileiro a assistir ao retorno da ideologia cristá, dos XVI e XVII, como orientação do Governo brasileiro no século XXI. No Ministério das Relaçôes Exteriores (MRE), órgão responsável pela promoção e pela defesa dos interesses do Brasil no exterior, a nomeação do Embaixador Ernesto Araújo como Chanceler trouxe a ideologia cristá ao epicentro da orientação da política externa do Brasil. Nesse mesmo contexto, a quantidade de assassinatos de lideranças indígenas no Brasil tem configurado um estado de guerra, alimentado, entre outras razóes, pela ausência da demarcação das terras indígenas prevista na Constituição Federal de 1988. Em 2019, A Articulação dos Povos Indígenas do Brasil (APIB) realizou a "Jornada Sangue Indígena: nenhuma gota a mais" em diversos países do continente europeu para denunciar a prática genocida do governo brasileiro. Não é comum estabelecer uma relação direta entre política externa e povos indígenas. Este artigo faz parte de um estudo teórico, ainda preliminar, que visa a contribuir para ampliação do campo de observaçáo empírica em análise de política externa (APE) e aponta para a necessidade da construçáo de um paradigma indigenista na política externa brasileira à luz do modelo paradigmático proposto pelo professor Amado Luiz Cervo. Trata-se da inclusão do componente indígena na formulação do interesse nacional após a promulgação da Constituiçáo Federal de 1988, bem como da vigência da Convenção 169, da Organização Internacional do Trabalho, relativa aos povos indígenas e tribais. Espera-se que a inclusão do componente indígena possa contribuir para outras análises acerca da formulação do interesse nacional, não apenas no Brasil, mas também, nos demais Estados nacionais signatários da Convenção 169/OIT.

PALAVRAS-CHAVE: Política externa. Povos indígenas. Análise do discurso. Conservadorismo. Bolsonarismo.

1 Universidade Federal do ABC (UFABC), Santo André - SP - Brasil. Mestrando no Programa de Relações Internacionais. Orcid: https://orcid.org/0000-0002-5740-7544. cesar.santos@funai.gov.br. 
Anuê Jaci: política externa e povos indígenas diante da inflexão conservadora e do bolsonarismo

\section{ANUÊ JACI: FOREIGN POLICY AND INDIGENOUS PEOPLES FACING CONSERVATIVE INFLECTION AND BOLSONARISM}

ABSTRACT: On the eve of the bicentenary of Brazil's Independence from Portugal (18222022), Jair Messias Bolsonaro's rise to the Presidency of the Republic challenges the Brazilian people to witness the return of Christian ideology, from the XVI and XVII, as the orientation of the Brazilian Government in the XXI century. In the Ministry of Foreign Affairs (MRE), the body responsible for promoting and defending Brazil's interests abroad, the appointment of Ambassador Ernesto Arauijo as Chancellor brought the Christian ideology to the epicentre of the orientation of Brazil's foreign policy. In this same context, the number of assassinations of indigenous leaders in Brazil has configured a state of war, fuelled, among other reasons, by the absence of the demarcation of indigenous lands provided for in the 1988 Federal Constitution. In 2019, the Articulation of Indigenous Peoples of Brazil (APIB) held the "Indigenous Blood: not one drop more" in several countries on the European continent to denounce the genocidal practice of the Brazilian government. It is not common to establish a direct relationship between foreign policy and indigenous peoples. This article is part of a theoretical study, still preliminary, that aims to contribute to the expansion of the field of empirical observation in foreign policy analysis (APE) and points to the need to build an indigenist paradigm to the Brazilian foreign policy in light of the paradigmatic model proposed by Professor Amado Luiz Cervo. This involves the inclusion of the indigenous component in the formulation of national interest after the promulgation of the Federal Constitution of 1988, as well as the validity of Convention 169, of the International Labour Organisation (ILO), concerning indigenous and tribal peoples. It is hoped that the inclusion of the indigenous component can contribute to other analyses of the formulation of national interest, not only in Brazil, but also in the other national states that are signatories of Convention 169/OIT.

KEYWORDS: Foreign policy. Indigenous peoples. Discourse analysis. Conservatism. Bolsonarism.

\section{Introdução}

Acreditemos no poder infinito da palavra, que é o logos criador.

O presidente Jair Bolsonaro está aqui, chegou até aqui, e nós com ele, porque diz o que sente. Porque diz a verdade. E isso é o logos.

Eu vou terminar falando do princípio e citando novamente São João, a abertura do Evangelho de São João, quando diz "en archê ên ho logos". 
O princípio era o logos. A palavra. O verbo. Archê, a última palavra em grego que eu vou dizer aqui hoje, significa princípio, tanto no sentido de início, quanto no sentido, principalmente, de força estruturante, princípio estruturante. A realidade, pelo menos a realidade humana, está estruturada em torno da linguagem, da palavra, do verbo, portanto do logos.

Tudo o que temos, tudo de que precisamos, é a palavra.

Ela está aprisionada, mas com amor e com coragem havemos de libertá-la.

Que Deus abençoe a todos vocês, aos que crêem [sic] e aos que náo crêem [sic], aos que estáo conosco e aos que ainda não estáo conosco. Que Deus abençoe o presidente Jair Bolsonaro e que Deus abençoe o Brasil. Anuê Jaci!

Muito obrigado. (ARAÚJO, 2019, grifo nosso). Crime de Genocídio

Para os efeitos do presente Estatuto, entende-se por "genocídio", qualquer um dos atos que a seguir se enumeram, praticado com intenção de destruir, no todo ou em parte, um grupo nacional, étnico, racial ou religioso, enquanto tal:

a) Homicídio de membros do grupo;

b) Ofensas graves à integridade física ou mental de membros do grupo;

c) Sujeição intencional do grupo a condições de vida com vista a provocar a sua destruição física, total ou parcial;

\footnotetext{
2 Segundo o Chanceler, o termo significaria "Ave Maria", a partir de uma suposta tradução que, ainda segundo o Ministro de Estado, seria do jesuíta José de Anchieta. Repare que a expressão foi utilizada no discurso do Ministro de Estado a título de saudação. Para saber mais sobre a estratégia de inculturação dos jesuítas no século XVI, (ALVES FILHO, 2010). Observa-se, ainda, que este autor não encontrou registro histórico desta saudação utilizada pelo Ministro de Estado, nem a referida tradução do jesuíta José de Anchieta com os termos utilizados pelo Ministro. Contudo, há o registro de um termo muito parecido, Anauê, com a letra "a", palavra que teria origem tupi e seria usada como saudação, tendo sido incorporada como saudação oficial pelo Movimento Integralista, especialmente durante o chamado governo provisório de Vargas (1930-1934). Os integrantes da Ação Integralista Brasileira (AIB) vestiam uniformes com camisas verdes e desfilavam pelas ruas como tropa militar gritando a saudação (ANAUÊ, 2020a, ANAUÊ, 2020b, ANAUÊ, 2020c). Optamos por fazer tal registro e utilizar os termos conforme a grafia usada no discurso, sem entrar no mérito de sua utilização normativa correta ou não, ou, ainda, se havia intertextualidade na fala, mas primando por seu efeito de sentido discursivo conforme sugerido literalmente pelo ministro em sua fala.
} 
d) Imposição de medidas destinadas a impedir nascimentos no seio do grupo;

e) Transferência, à força, de crianças do grupo para outro grupo.

(BRASIL, 2002).

Desde os trabalhos da Assembleia Nacional Constituinte, em 1987, os movimentos sociais indígenas asseguraram uma nova forma de relacionamento entre os povos indígenas e o Estado brasileiro. Os povos indígenas assumiram um novo lugar, político e institucional, a partir da promulgação da Constituiçáo Federal de 1988 (LACERDA, 2008).

O novo lugar dos povos indígenas poderia ter sido aquele semelhante aos dos demais grupos de interesse que atuam no Congresso Nacional (as bancadas evangélicas, do agronegócio, do esporte, dos professores etc.) e que se organizam para que as autoridades implementem a agenda de seus respectivos interesses. Entretanto, os integrantes da Assembleia Nacional Constituinte, os constituintes originários, estabeleceram que a relação entre o Estado brasileiro e os povos indígenas tivesse uma natureza específica, a partir da Constituição de 1988. (SILVA, 2018).

A Assembleia Nacional Constituinte, ao tratar da agenda dos povos indígenas, rompeu com a perspectiva assimilacionista (JUNIOR, 2018) do Estado brasileiro em relação aos índios. A partir de 1988, a Constituição Federal passou a assegurar aos índios o direito de serem indígenas.

Nos termos do artigo 231, caput, da Constituição Federal: "São reconhecidos aos índios sua organização social, costumes, línguas, crenças e tradições, e os direitos originários sobre as terras que tradicionalmente ocupam, competindo à União demarcá-las, proteger e fazer respeitar todos os seus bens" (BRASIL, 1990).

No âmbito das relaçóes internacionais, por seu turno, o texto constitucional também estabeleceu princípios fundamentais para a ação da República Federativa do Brasil. A autodeterminação dos povos, bem como a integração dos povos da América Latina são considerados princípios fundamentais da República, (BRASIL, 1990, Título I, especialmente, os artigos 4, III e caput).

Não bastasse o reconhecimento dos direitos originários das terras indígenas tradicionalmente ocupadas (BRASIL, 1990, artigo 231, caput), bem como a busca pela integração dos povos da América Latina como princípio fundamental da República (BRASIL, 1990, 4, Único), seria importante lembrar que as terras indígenas pertencem à União (BRASIL, 1990, Art. 20, XI). 
Sobre as terras indígenas, por exemplo, incidem duas espécies de proteção constitucional $^{3}$ : os direitos de propriedade (bens pertencentes à Uniáo) e os direitos originários (direitos anteriores à formação do Estado Nacional reconhecidos pelo Estado). Esta complementariedade de garantias constitucionais sobre as terras indígenas consagra uma relação jurídica conhecida por Indigenato (MENDES JR., 1912).

\section{O indigenato e a política externa brasileira}

Para a devida compreensão da relação direta entre a política externa do governo Bolsonaro e os povos indígenas, é necessário ampliar o horizonte de observação empírica. Esse recorte histórico se inicia em 1989, quando o Brasil se torna signatário da Convenção 169, da Organização Internacional do Trabalho, relativa aos povos indígenas e tribais, e se encerra, em 2019, com a ascensáo do discurso cristão na política externa brasileira, que resgata a memória colonial do Brasil.

Conforme introduzido acima, em 1989, no contexto da mudança do relacionamento institucional entre povos indígenas e o Estado, o Brasil se tornou signatário da Convenção 169, da Organização Internacional do Trabalho (OIT), relativa aos povos indígenas e tribais ${ }^{4}$. Desde entâo, a República Federativa do Brasil está sujeita a obrigaçóes jurídicas no âmbito internacional nos termos do Direito Internacional Público. Exemplo emblemático destas obrigaçóes jurídicas refere-se aos votos do Brasil nos organismos internacionais acerca de temas que afetam os povos indígenas diretamente. Os votos do Brasil teriam sido realizados em conformidade com os protocolos de consulta a que se refere a Convenção 169/OIT? (OIT, 1989).

Caso as referidas consultas não tenham sido realizadas e, ainda assim, o Brasil tenha proferido os votos nos organismos internacionais, quais seriam as consequências jurídicas para a República Federativa do Brasil no âmbito do Direito internacional?

No âmbito doméstico, por sua vez, o Brasil internalizou a Convenção 169/ OIT ao ordenamento jurídico em 2004, durante o governo Luiz Inácio Lula da

\footnotetext{
3 O status de proteção constitucional em relação às terras indígenas implica uma relação regida pelo Direito Público, o que afasta, por exemplo, as relações de propriedade estabelecidas no Direito Civil, que trata da propriedade privada.

4 A Sexta Câmara de Coordenação e Revisão do Ministério Público Federal publicou o Manual de Jurisprudência dos Direitos Indígenas em 2019. Trata-se da compilação dos principais julgados, nacionais e internacionais, que nos atualizam sobre os parâmetros jurídicos que tem orientado a implementação da legislação indigenista.
} 
Silva, por meio do Decreto Presidencial 5051/20045. A partir desse decreto, as obrigações jurídicas foram ampliadas. Desde 2004, os órgãos do Governo Federal devem realizar, por exemplo, consultas prévias, livres e informadas aos povos indígenas nos temas que lhes afetam diretamente (OIT, 1989, art. 6).

Não apenas a adesão da República Federativa do Brasil à Convenção 169/ OIT, em 1989, mas também a internalização deste tratado internacional ao ordenamento jurídico pátrio, em 2004 reafirmam os novos parâmetros de relacionamento institucional entre os povos indígenas e o Estado brasileiro já estabelecidos pela Constituição Federal de 1988 (BRASIL, 1990, art. 231). O Presidente da República, Jair Messias Bolsonaro, está submetido a esses parâmetros, na condiçáo de Chefe de Estado e de Chefe de Governo ${ }^{6}$.

Embora o escopo deste artigo não permita desenvolver questóes acerca das responsabilidades jurídicas segundo as normas do Direito Internacional Público, ou mesmo do Direito brasileiro, compreendemos a oportunidade de trazer esta reflexão do campo jurídico para nos inspirar à realização de incursóes acadêmicas interdisciplinares que investigue a relação entre a política externa e os povos indígenas.

\section{Política externa e povos indígenas: uma agenda de pesquisa necessária}

A política externa brasileira encontra-se no rol de políticas públicas voltadas ao desenvolvimento nacional e regional. Apenas a título ilustrativo, o artigo 7 da Convenção 169/OIT estabelece que “[...] os povos indígenas devem participar da elaboração, da implementação e da avaliação dos planos e programas de desenvolvimento nacional e regional suscetíveis de lhe afetar diretamente" $\left(\right.$ BIT, 2013) ${ }^{7}$.

No âmbito dos estudos de relações internacionais, as análises de política externa (APE), também não têm produzido avaliaçóes acerca da participação dos povos indígenas na formulação da política externa. Nesse sentido, existe uma

\footnotetext{
5 Disponível em: http:/www.planalto.gov.br/ccivil_03/_Ato2004-2006/2004/Decreto/D5051.htm. Acesso em: 24 ago. 2020. Acesso em: 21 jan. 2020.

6 Artigo 6 do Estatuto de Roma, que rege o Tribunal Penal Internacional disponível em: http://www.planalto.gov. br/ccivil_03/decreto/2002/D4388.htm. Acesso em: 24 ago. 2020.

7 A Convenção 169/OIT, internalizada pelo Decreto Presidencial 5051/2004, determina o estabelecimento de protocolos formais de consulta. A Fundação Nacional do Índio (FUNAI), responsável pela coordenação da política indigenista do Estado brasileiro, poderia auxiliar o Ministério das Relações Exteriores na mediação das referidas Consultas. Seria oportuno que o Brasil estabelecesse, nesse sentido, uma Portaria Interministerial que aproximasse a política externa e a política indigenista no âmbito da Administração Pública Federal, a exemplo do que ocorre em relação à política ambiental (Portaria Interministerial 60, de 24 de Março de 2015).
} 
lacuna para investigação científica. De fato, a relação entre política externa e povos indígenas ainda é um tema inexplorado na contemporaneidade (KEMER; PEREIRA, 2018).

A área de política externa brasileira poderia oferecer uma linha de pesquisa que investigasse a relação entre política externa e povos indígenas. Seria necessário se valer de investigaçóes interdisciplinares de áreas afins, não apenas do Direito, mas também da Linguística, da História, entre outras. Entendemos que as contribuiçôes interdisciplinares poderão dialogar com recentes estudos de APE acerca da relação, por exemplo, entre política externa e democracia (LOPES, 2013), e política externa e classes sociais (BERRINGER, 2015).

No âmbito dos estudos linguísticos, a Análise do Discurso ofereceria procedimentos para identificar o lugar os povos indígenas acerca da orientaçáo da política externa nos textos oficiais do Estado brasileiro. Após a internalização da Convenção 169/OIT ao ordenamento jurídico pátrio, em 2004, os povos indígenas assumiram o seu lugar de fala na formulação do interesse nacional? A evidente ausência do componente indígena na formulação da política externa brasileira implica reconhecer a produção de um silêncio cujos efeitos merecem investigação científica (ORLANDI, 2003).

Uma das hipóteses para a produção deste silêncio refere-se à composição dos (as) formuladores (as) da política externa brasileira. Durante o período da Era Lula, a burguesia interna teria constituído um bloco de poder que reunia diversos setores econômicos interessados na promoção do interesse nacional, em contraposição aos interesses da burguesia compradora, orientada pelo fluxo do capital internacional (BERRINGER, 2015).

Vale registrar que, no âmbito do Itamaraty, o corpo diplomático brasileiro é constituído, majoritariamente, por homens brancos, oriundos de classe média brasileira; os diplomatas são selecionados a partir de concurso público de provas que privilegiam competências e habilidades incompatíveis com a organização social, costumes e línguas dos povos indígenas, reconhecidos pelo Estado brasileiro (BRASIL, 1990, art.231).

É verdade que o Ministério das Relações Exteriores dispóe de uma política de ação afirmativa pioneira desde 2002. Entretanto, essa política de ação afirmativa não inclui os povos indígenas. Os estudos provenientes da teoria crítica pós-colonial oferecem algumas alternativas para reflexão acerca da produçáo deste silêncio em relação aos povos indígenas. Uma das razóes encontra-se nos efeitos históricos do processo colonizador (BRAYBOY, 2005; OLIVEIRA, 2011).

O discurso de posse do Embaixador Ernesto Araújo no cargo de Ministro de Estado das Relaçốes Exteriores do Brasil intensifica a mentalidade conserva- 
dora na formulação do interesse nacional ${ }^{8}$. Não se trata de um fenômeno social brasileiro apenas. Desde a década passada, esse processo antidemocrático tem sido intensificado a partir da ascensão de governos ultraconservadores em diversos países. (BROWN, 2019).

No âmbito dos estudos históricos, a literatura contemporânea acerca da relação entre política externa e povos indígenas encontra oportunidades para novas investigaçóes científicas (CARNEIRO; ROSSI, 2019). Qual tem sido o lugar dos povos indígenas no contexto da política externa brasileira após a promulgação da Constituição Federal de 1988? Tradicionalmente, a diplomacia brasileira contribui para a formulação da identidade do Brasil, entretanto, é forçoso reconhecer que as referências do pensamento diplomático brasileiro contemporâneo foram herdadas da época do Segundo Reinado, ainda no século XIX: o liberalismo jurídico e o conservantismo moderado para assegurar a unidade nacional (RICUPERO, 2017).

Novamente, uma das hipóteses para a produção do silêncio em relação aos povos indígenas na política externa contemporânea se refere à composição dos (as) formuladores (as) do interesse nacional. Dawisson Belém Lopes, pesquisador da Universidade Federal de Minas Gerais, observa que o processo de redemocratização, após 1985 , teria ensejado certa abertura na formulação da política externa brasileira. Durante a Era Lula, o Itamaraty teria promovido a criação de mecanismos formais de consulta a diversos setores da sociedade brasileira. Ainda assim, é evidente a manutenção de um perfil republicano-aristocrático no Itamaraty (LOPES, 2013).

\section{9: Anuê Jaci, a inflexão conservadora}

Em 1988, a República Federativa do Brasil optou por uma nova forma de relacionamento político e institucional com os povos indígenas. Em relação às terras tradicionalmente ocupadas pelos indígenas, por exemplo, o Estado brasileiro reconhece o direito originário dos povos indígenas. Como vimos, essa relação, estabelecida no texto constitucional determinou, também, que as terras indígenas pertencessem à Uniâo. A dupla incidência de proteção constitucional sobre as terras indígenas (direitos originários e propriedade da Uniáo) afasta a relação jurídica da propriedade privada sobre as terras indígenas e recepciona o instituto do Indigenato. (SILVA, 2018).

\footnotetext{
8 O discurso de posse, bem como os demais discursos do Chanceler brasileiro que reforçam um modelo liberalconservador podem ser encontrados disponíveis em: http://www.itamaraty.gov.br/pt-BR/discursos-artigos-eentrevistas-categoria/ministro-das-relacoes-exteriores-discursos. Acesso em: 24 ago. 2020.
} 
Portanto, é nesse sentido que o discurso do Ministro de Estado das Relaçóes Exteriores, Ernesto Araújo, deveria se adequar.

Vejamos:

Eu me lembro da emoção que eu senti pela primeira vez, quando era Terceiro Secretário, que subi as escadas para este terceiro andar, e vi, logo ao subir a escada, o quadro da Coroação de Dom Pedro I e o quadro do Grito do Ipiranga. Imediatamente, eu, que tinha 22 anos, me lembrei de quando tinha 5 anos e assisti maravilhado no cinema ao filme "Independência ou Morte", com Tarcísio Meira e Glória Menezes. E pensei: entáo tudo isso existe, né? Tudo isso existe... e tudo isso é aqui!

Eu me lembro desse momento muito marcadamente e eu percebi: olha, isso aqui não é simplesmente uma repartição pública, isso aqui é uma espécie de um santuário. É uma espécie de túnel do tempo, onde os heróis estão vivos, os heróis famosos e os heróis anônimos, onde nós convivemos com os descobridores, com Alexandre de Gusmão, José de Anchieta, com D. João VI, com os Imperadores e as princesas, com os bandeirantes e os abolicionistas, com os seringueiros e garimpeiros e tropeiros que construíram essa nação, e até mesmo com o estranho caso de um Barão monarquista que se tornou o grande ídolo da República.

Eu não sei se alguns de vocês já tenham assistido provavelmente a um seriado espanhol chamado Ministerio del Tiempo. Eu recomendo. E eu diria que o Itamaraty, em certo sentido, não é somente um Ministério das Relaçôes Exteriores, é também um Ministério do Tempo. Como talvez nenhuma outra instituição no Brasil, nós temos a responsabilidade de proteger e regar esse tronco histórico multissecular por onde corre a seiva da nacionalidade (ARAÚJO, 2019).

O texto constitucional expressa o rompimento do Estado brasileiro com a perspectiva tutelar do Estado em relação aos povos indígenas ${ }^{9}$. Se esse novo lugar dos povos indígenas inclui signos, textos, objetos, práticas e estratégias próprias da organização social desses povos, então, essas mudanças impactaráo todo o conjunto (ALDAMA, 2019).

Vejamos, novamente:

\footnotetext{
9 Nos termos do artigo 231, caput, da Constituição Federal, "São reconhecidos aos índios sua organização social, costumes, línguas, crenças e tradições, e os direitos originários sobre as terras que tradicionalmente ocupam, competindo à União demarcá-las, proteger e fazer respeitar todos os seus bens”. (BRASIL, 1990).
} 
Anuê Jaci: política externa e povos indígenas diante da inflexão conservadora e do bolsonarismo

Queria dizer que nós não precisamos e não vamos abrir os quadros do Itamaraty para pessoas de fora da carreira, além dos casos que já existem. O presidente Bolsonaro confia plenamente na capacidade dessa casa e dessa carreira de implementar a sua política. (ARAÚJO, 2019).

Mais adiante:

Nós temos tradições, é claro, mas precisamos empregá-las como estímulo para buscar a verdade e a liberdade, como serviço à pátria, como serviço a todos os brasileiros, tanto os mais humildes, quanto os mais afortunados do nosso povo, esse povo que uma ideologia perversa não mais divide (ARAÚJO, 2019).

O reconhecimento do Estado brasileiro em relação a formas de vidas e de organização social dos povos indígenas náo aparece no discurso de posse do Ministro de Estado das Relaçóes Exteriores, o Embaixador Ernesto Araújo:

Eu vou terminar falando do princípio e citando novamente São João, a abertura do Evangelho de São João, quando diz "en archêe ên ho logos". O princípio era o logos. A palavra. O verbo. Archê, a última palavra em grego que eu vou dizer aqui hoje, significa princípio, tanto no sentido de início, quanto no sentido, principalmente, de força estruturante, princípio estruturante. A realidade, pelo menos a realidade humana, está estruturada em torno da linguagem, da palavra, do verbo, portanto do logos. Tudo o que temos, tudo de que precisamos, é a palavra. Ela está aprisionada, mas com amor e com coragem havemos de libertá-la. Que Deus abençoe a todos vocês, aos que crêem $[s i c]$ e aos que não crêem $[s i c]$, aos que estáo conosco e aos que ainda não estão conosco. Que Deus abençoe o presidente Jair Bolsonaro e que Deus abençoe o Brasil.

Anuê Jaci!

Muito obrigado (ARAÚJO, 2019, grifo nosso).

Na perspectiva dos estudos linguísticos, seria oportuno pensar e identificar o lugar dos povos indígenas na política externa brasileira contemporânea com base no discurso oficial do Brasil. O pronunciamento, por ocasiáo da posse do Embaixador Ernesto Araújo como Ministro de Estado das Relaçóes Exteriores 
do Brasil, constitui o marco final do nosso recorte histórico (1989-2019). Essa opção decorre, entre outras razóes, da função que o texto do discurso de posse exerce sobre a orientação da política externa do Brasil para os próximos anos. $\mathrm{O}$ modo de inserção do Brasil no cenário internacional e, especialmente, os votos proferidos pela República Federativa do Brasil no âmbito internacional encontram expressão no discurso de posse ${ }^{10}$.

Em Análise do Discurso, instala-se uma tensão entre constituição e formulação, em que a ideologia se instala. A constituição se subsume ao movimento de repetição. Consome-se como a sustentação do saber discursivo, o interdiscurso. Reunindo as formas de constituição e interdiscurso, uma formação ideológica toma corpo em uma formação discursiva (ORLANDI, 2003).

A formação discursiva encerra os sentidos possíveis de uma situação de comunicação e de um sujeito. Há significados associados à escolha do vocabulário. Certa visão de mundo será delimitada pela formação discursiva que se instaura, especialmente quando se reconhece a composição do grupo político eleito.

Entretanto, há uma força contrária, que nasce no intradiscurso, a força da formulação. Fundamentada numa disputa entre memória e atualidade, abre-se espaço para a polissemia. Há imprevisibilidade não apenas na relação do sujeito com o sentido, mas também nas formas de controle da interpretação, determinadas de força histórica. (ORLANDI, 2003)

Segundo o Chanceler Ernesto Araújo,

Tudo o que temos, tudo de que precisamos, é a palavra. Ela está aprisionada, mas com amor e com coragem havemos de libertá-la. Que Deus abençoe a todos vocês, aos que crêem $[s i c]$ e aos que náo crêem [sic], aos que estão conosco e aos que ainda não estão conosco. Que Deus abençoe o presidente Jair Bolsonaro e que Deus abençoe o Brasil.

Anuê Jaci! (ARAÚJO, 2019, grifo nosso).

\footnotetext{
${ }_{10}$ Após a data do pronunciamento de posse do Ministro de Estado das Relações Exteriores, Ernesto Araújo, em 02 de janeiro de 2019, novos eventos ocorridos na execução da política externa brasileira, como a participação de uma liderança indígena (não reconhecida pelas organizações indígenas), na delegação brasileira, por ocasião da participação do Brasil na Assembleia Geral da ONU, reforçam a análise proposta neste trabalho. Disponível em: http://agenciabrasil.ebc.com.br/politica/noticia/2019-09/presidente-jair-bolsonaro-discursa-na-assembleia-geralda-onu. Acesso em: 24 ago. 2020.
} 


\section{O Bolsonarismo (ou o Trumpismo ${ }^{11}$ Tupiniquim)}

Em 2019, a República Federativa do Brasil assiste à ascensão da extrema direita ao poder político institucional. No âmbito do Ministério das Relaçôes Exteriores $^{12}$, o discurso de posse do Chanceler Ernesto Araújo aponta para uma aliança ideológica entre liberalismo e conservadorismo que culminaram em um fenômeno social que, no Brasil, passou a ser conhecido por Bolsonarismo. Entre suas bases de apoio, há a tendência a relacionar o Bolsonarismo à vitória eleitoral à presidência dos Estados Unidos da América (EUA), em 2016, por Donald Trump, por algumas semelhanças no discurso dos políticos e nas disseminaçôes de notícias pelos comitês de campanha de $\operatorname{ambos}^{13}$. Há, ainda, a sempre presente referência brasileira aos valores adotados pelo governo americano atualmente.

Vejamos:

Por isso admiramos os Estados Unidos da América, aqueles que hasteiam sua bandeira e cultuam seus heróis [...] Por isso admiramos a nova Itália, por isso admiramos a Hungria e a Polônia, admiramos aqueles que se afirmam e náo aqueles que se negam. O problema do mundo não é a xenofobia, mas a oikofobia - de oikos, oikía, o lar. Oikofobia é odiar o próprio lar, o próprio povo, repudiar o próprio passado [...] (ARAÚJO, 2019, grifo nosso).

Mais adiante, o discurso de posse do Chanceler faz referência à ideologia cristã como orientação da política externa brasileira:

Os senhores me perguntarão: e como faremos isso? Pela palavra. Acreditemos no poder infinito da palavra, que é o logos criador. O presidente Jair Bolsonaro está aqui, chegou até aqui, e nós com ele, porque diz o que sente. Porque diz a verdade. E isso é o logos. Eu vou terminar falando

\footnotetext{
${ }^{11}$ Em 2017, após a vitória eleitoral de Donald Trump, o atual Ministro de Estado das Relações Exteriores, publicou um artigo no Cadernos de Política Exterior, intitulado Trump e o Ocidente. Para ler esse texto na íntegra, ver: http:// funag.gov.br/loja/download/CADERNOS-DO-IPRI-N-6.pdf. Acesso em: 24 ago. 2020.

${ }^{12}$ A execução política externa do Brasil, no Governo Bolsonaro, não está centralizada no Itamaraty. Por limitações de espaço neste artigo, restringiremos a análise ao Ministério das Relações Exteriores, embora o Ministério da Fazenda, Ministério da Agricultura, o Ministério do Meio Ambiente, entre outros, também, disponham de agendas internacionais que afetam diretamente os povos indígenas, vinculando-os à exigência da implementação da Convenção 169/OIT.

${ }^{13}$ Por um lado, vemos uma inflexão da política externa conservadora; por outro lado, identificamos elementos ultraconservadores associados à ascensão da extrema direita em torno dos valores do Ocidente, incompatíveis com o reconhecimento da organização dos povos indígenas, reconhecidos pela Constituição Federal de 1988.
} 
do princípio e citando novamente São João, a abertura do Evangelho de São João, quando diz "en archê ên ho logos". O princípio era o logos. A palavra. $\mathrm{O}$ verbo. Archê, a última palavra em grego que eu vou dizer aqui hoje, significa princípio, tanto no sentido de início, quanto no sentido, principalmente, de força estruturante, princípio estruturante. A realidade, pelo menos a realidade humana, está estruturada em torno da linguagem, da palavra, do verbo, portanto do logos (ARAÚJO, 2019, grifo nosso).

Torna-se forçoso reconhecer a ascensão da política antidemocrática no Brasil, como vem ocorrendo em outros países, tais como, a Polônia, Hungria e os EUA. O tripé "família- tradição- religião" a que se refere a filósofa e feminista norte-americana, Wendy Brown, esvazia o Estado Democrático de Direito com base nos escombros da crise financeira de 2008 e na reação conservadora (BROWN, 2019).

No Brasil, os povos indígenas já não vinham participando da formulação da política externa brasileira a despeito da Convenção 169/OIT, que vincula a formulação de políticas públicas aos povos indígenas diretamente afetados ${ }^{14}$. A invisibilidade dos povos indígenas se explica, em parte, pelo perfil aristocrático-republicano a que se refere Dawisson Belém Lopes, em "Política Externa e Democracia no Brasil” (LOPES, 2013). Em 2019, entretanto, o Bolsonarismo adiciona uma orientação genocida ${ }^{15}$ à política externa brasileira, nos termos do Estatuto de Roma, que regula o Tribunal Penal Internacional ${ }^{16}$. A Jornada Sangue Índigena: nenhuma gota a mais, organizada pela Articulaçáo dos Povos Indígenas do Brasil, em 2019, corrobora o artigo 6 do Estatuto de Roma, que regulamenta o Tribunal Penal Internacional (APIB, 2019).

A análise do discurso de posse do Embaixador Ernesto Araújo registra a prevalência da agenda econômica baseada no agronegócio, que avança, por exemplo, na região Amazônica e impacta a organização social dos povos indíge-

\footnotetext{
${ }^{14}$ Os limites deste artigo não permitem a realização da análise da política externa entre 1989 e 2019. Para breve análise do período, ver Ricupero (2017, p.515-652).

15 Para saber mais: http://apib.info/2019/10/30/acompanhe-a-jornada-sangue-indigena-nenhuma-gota-a-mais/. Acesso em: 24 ago. 2020.

16 "Art. 6 Para os efeitos do presente Estatuto, entende-se por "genocídio", qualquer um dos atos que a seguir se enumeram, praticado com intenção de destruir, no todo ou em parte, um grupo nacional, étnico, racial ou religioso, enquanto tal:

a) Homicídio de membros do grupo;

b) Ofensas graves à integridade física ou mental de membros do grupo;

c) Sujeição intencional do grupo a condições de vida com vista a provocar a sua destruição física, total ou parcial;

d) Imposição de medidas destinadas a impedir nascimentos no seio do grupo;

e) Transferência, à força, de crianças do grupo para outro grupo". (BRASIL, 2002).
} 
nas, quilombolas e ribeirinhos que vivem na floresta em processo de devastação e de queimadas.

Ernesto Araújo assim se refere ao agronegócio:

Um dos instrumentos do globalismo, para abafar aqueles que se insurgem contra ele, é espalhar que, para fazer comércio e negócios, não se pode ter ideias nem defender valores. Nós provaremos que isso é completamente falso. O Itamaraty terá, a partir de agora, o perfil mais elevado e mais engajado que jamais teve na promoção do agronegócio, do comércio, dos investimentos e da tecnologia (ARAÚJO, 2019).

\section{Considerações finais: a implementação da convenção 169/OIT nesses tempos conservadores e antidemocráticos}

A Convenção 169/OIT prevê a obrigatoriedade dos Estados signatários realizar consultas prévias, livres e informadas aos povos indígenas diretamente afetados por meio de protocolos formais de consulta (BIT, 2013). No caso da agenda da política externa, sua formulação e consecução impactam diretamente o desenvolvimento do Brasil e, portanto, os povos indígenas.

No discurso de posse do Chanceler Ernesto Araújo, o Itamaraty resgata uma narrativa histórica ainda do período colonial:

Nós passamos anos na escola, quase todos nós, eu acho, escutando que foi a ganância ou o anseio de riqueza, ou pior ainda, o acaso, que formou o Brasil, mas não foi. Foram o amor, a coragem e a fé que trouxeram até aqui, através do oceano, através das florestas, pessoas que nos fundaram, pessoas que disseram coisas como esta que vou ler agora:

Anuê Jaci, etinisemba-ê

Indê irú manunhề

Yara rekô embobeuká tupirã

Rekôku ya subi

Embobeuká tupirabê

Nge membyrá Tupã

Essa é a Ave Maria em tupi, na versão original do Padre José de Anchieta, onde ele traduz Maria por Jaci, a lua, Anuê Jaci, e Jesus por Tupã, o trovão. E aqui precisamos da Aletheia. O desesquecimento. Precisamos libertar a nossa memória histórica da qual essa modesta oração faz parte. 
Para libertar o Itamaraty através da verdade, precisamos recuperar o papel do Itamaraty como guardião da continuidade da memória brasileira. (ARAÚJO, 2019, grifo nosso).

O texto da Constituição Federal, no entanto, estabelece que a República Federativa do Brasil é Estado Democrático de Direito (BRASIL, 1990, Art. 1). O caráter laico do Estado brasileiro é incompatível com o retorno da ideologia cristã como elemento da política externa do país.

Os estudos linguísticos podem oferecer excelentes contribuiçóes à análise da relação entre política externa e povos indígenas. No texto do discurso de posse do Chanceler Ernesto Araújo, a Semiótica nos emprestaria a investigação acerca, por exemplo, da morfologia do discurso da crise da identidade nacional, o que poderia nos levar a entender melhor a sua consequente imprevisibilidade política, primando por análises de estruturas que apontam para a construção de sentidos em um discurso. Seria possível realizar um estudo acerca das dinâmicas de continuidade e de descontinuidades culturais e históricas.

Nesse contexto, a implementação da Convenção 169/OIT poderia se transformar na oportunidade de a política externa brasileira se adequar aos princípios constitucionais que regem as relaçóes internacionais do Brasil. ${ }^{17}$ Sustentamos que a agenda do desenvolvimento sustentável, nas suas dimensóes econômicas, sociais e ambientais, encontra-se no cerne do paradigma indigenista, ainda silenciado na política externa brasileira, porém, não menos paradigmático.

\footnotetext{
17 Nos termos do Artigo 4 da Constituição Federal de 1988 (BRASIL, 1990):

A República Federativa do Brasil rege-se nas suas relações internacionais pelos seguintes princípios:

I. Independência Nacional;

II. Prevalência dos direitos humanos;

III. Autodeterminação dos povos;

IV. Não intervenção;

V. Igualdade entre os Estados;

VI. Defesa da paz;

VII. Solução pacífica dos conflitos;

VIII. Repúdio ao terrorismo e ao racismo;

IX. Cooperação entre os povos para o progresso da humanidade;

X. Concessão de asilo político
}

Parágrafo único: A República Federativa do Brasil buscará a integração econômica, política, social e cultural dos povos da América Latina, visando à formação de uma comunidade latino-americana de nações.

Cada um desses incisos seria oportuno para justificar a necessidade da implementação da Convenção 169/OIT no âmbito da política externa. Pelas limitações deste artigo, a autor convida os leitores e as leitoras a visitarem a obra Direitos dos Povos Indígenas em Disputa, organizado pela professora Manuela Carneira da Cunha e pelo professor Samuel Barbosa. Editora UNESP 2018. Nele, não se encontra a relação entre política externa e povos indígenas, como mencionamos neste artigo, mas, e aqui é fundamental, encontram-se os principais temas que envolvem a causa indígena onde os movimentos sociais indígenas já avançaram, apesar de um Estado Democrático de Direito que ainda está por ser consolidado. 
Segundo o professor Amado Cervo, os paradigmas desenvolvimentista, neoliberal e logístico teriam coabitado na execução da política externa brasileira a partir de 1989 (CERVO, 2008).

A partir da Conferência das Naçóes Unidas sobre o Meio Ambiente e o Desenvolvimento, a ECO-92, bem como da organização da Conferência Mundial dos Povos Indígenas sobre Território, Meio Ambiente e Desenvolvimento, a KARIOCA, esta, organizada por movimentos sociais indígenas, em 1992, ambas no Brasil, parece ter havido uma aproximação ao respeito à organização social, costumes, línguas e tradiçóes dos povos indígenas (TERENA, 2019) ${ }^{18}$.

A partir de 2019, a inflexão conservadora da política externa brasileira e o Bolsonarismo constituíram desafios aos povos indígenas e também trazem uma oportunidade de investigar, ainda com mais elementos, a existência de um paradigma que está sendo silenciado desde 1989. A implementação da Convenção 169/OIT na política externa brasileira, nesse contexto histórico, até poderia ser institucionalizada por este governo, mas apenas como parte do espetáculo de uma política externa incongruente.

\section{REFERÊNCIAS}

ALDAMA, J. A. Crise et imprévisibilité. In: ESTAY STANGE, P.; HACHETTE; HORREIN, R. (éd.). Sens à l'horizon: Hommage à Denis Bertrand. Limoges: Lambert-Lucas, 2019. p. 53-60.

ALVES FILHO, P. E. As traduçóes do jesuíta José de Anchieta para o tupi no Brasil Colonial. Tradterm, São Paulo, v. 17, p. 11-30, 2010. Disponível em: https://doi. org/10.11606/issn.2317-9511.tradterm.2010.40280. Acesso em: 9 fev. 2020.

ANAUÊ. Michaelis. Disponível em: http://michaelis.uol.com.br/busca?id=mLKk. Acesso em 28 fev. 2020a.

ANAUE. Priberam. Disponível em: https://dicionario.priberam.org/anau\%C3\%AA. Acesso em 28 fev. 2020b.

ANAUÊ. Wikipedia. Disponível em: https://pt.wikipedia.org/wiki/Anau\%C3\%AA. Acesso em 28 fev. 2020c.

\footnotetext{
${ }^{18}$ Dois temas acerca da relação entre política econômica do Governo Bolsonaro mereceriam um artigo específico: o arrendamento de terras indígenas e a exploração de recursos minerais em terras indígenas. Em razão das dimensões deste artigo, convidamos os leitores interessados no tema a interpretar o discurso liberal à luz do instituto do Indigenato a que este autor fez referência no início deste artigo.
} 
APIB. Jornada Sangue Indígena: Nenhuma Gota mais! Mídia Ninja, 2019. Disponível em: https://www.youtube.com/watch?v=8w_w6PqMPv0. Acesso em: 10 jan. 2020.

ARAÚJO, E. Discurso do ministro Ernesto Araújo durante cerimônia de posse no Ministério das Relaçóes Exteriores. Brasília: Itamaraty, jan. 2019. Disponível em: http://www.itamaraty.gov.br/pt-BR/discursos-artigos-e-entrevistas-categoria/ministrodas-relacoes-exteriores-discursos/19907-discurso-do-ministro-ernesto-araujo-durantecerimonia-de-posse-no-ministerio-das-relacoes-exteriores-brasilia-2-de-janeirode-2019. Acesso em: 10 out. 2019.

BRASIL. Presidência da República. Decreto no 4.388, de 25 de setembro de 2002. Promulga o Estatuto de Roma do Tribunal Penal Internacional. Diário Oficial, Brasília, 2002. Disponível em http://www.planalto.gov.br/ccivil_03/decreto/2002/ D4388.htm. Acesso em: 12 nov. 2019.

BRASIL. [Constituição (1988)]. Constituição da República Federativa do Brasil: promulgada em 5 de outubro de 1988. 4. ed. São Paulo: Saraiva, 1990.

BRAYBOY, B. M. J. Toward a Tribal Critical Race Theory of Education. The Urban Review, Dordrecht, v.37, p. 425-446, 2005. Disponível em: https://doi.org/10.1007/ s11256-005-0018-y. Acesso em: 10 jan. 2020.

BERRINGER, T. A burguesia brasileira e a política externa nos governos FHC e Lula. Curitiba: Appris, 2015.

BIT. Manuel à usage des mandants tripartites de l'OIT: Comprendre la convention ( $\mathrm{n}^{\circ}$ 169) relative aux peuples indigènes et tribaux, 1989. Genève: Bureau international du Travail, 2013. Disponível em: https:/www.ilo.org/wcmsp5/groups/public/--ed_norm/---normes/documents/publication/wcms_211976.pdf. Acesso em: $05 \mathrm{dez}$. 2019

BROWN, W. Nas ruínas do neoliberalismo: a ascensão da política antidemocrática no Ocidente. Trad. Mario A. Marino e Eduardo A Camargo Santos. São Paulo: Politeia, 2019.

CARNEIRO, M. L. T.; ROSSI, M. S. (org.). Índios no Brasil: vida, cultura e morte. São Paulo: IHF; LEER/USP; Intermeios, 2019.

CERVO, A. L. Inserçáo Internacional: formação dos conceitos brasileiros. Saraiva: São Paulo, 2008.

JUNIOR, J. J. A. A Constituiçẫo de 1988 e os direitos indígenas: uma prática assimilacionista? In: CUNHA, M. C. da; BARBOSA, S (org.). Direitos dos povos indígenas em disputa. São Paulo: Ed. da Unesp, 2018. p. 175-236. 
KEMER, T.; PEREIRA, A. E. A análise da política externa na academia brasileira: um mapeamento quantitativo e qualitativo das agendas de pesquisa (1998-2017) In: ENCONTRO DA ASSOCIAÇÃO BRASILEIRA DE CIÊNCIA POLÍTICA, 11., Curitiba. Anais [...], Curitiba: UFPR, 2018. Disponível em: https://cienciapolitica. org.br/system/files/documentos/eventos/2019/05/analise-politica-externa-academiabrasileira-mapeamento.pdf. Acesso em: 01 out. 2019.

LACERDA, R. Os Povos Indígenas e a Constituinte (1987-1988). Brasília: Conselho Indigenista Missionário, 2008.

LOPES, D. B. Política Externa e democracia no Brasil. São Paulo: Ed. da UNESP, 2013.

MENDES JUNIOR, J. Os indigenas do Brazil, seus direitos individuaes e politicos. São Paulo: Typ. Hennies Irmãos, 1912. Edição Fac-similar, Comissão Pró-Índio. Disponível em: https://cpisp.org.br/wp-content/uploads/2019/02/Os_ Indigenas_do_Brazil.pdf. Acesso em: 10 nov. 2019.

OLIVEIRA, J.L.L. Negros e diplomacia: presença de afro-descendentes no Itamaraty: Estudo comparado entre o Ministério das Relaçóes Exteriores do Brasil e o Departamento de Estado norte-americano. 2011. Dissertação (Mestrado em Diplomacia) - Instituto Rio Branco, Brasília, 2011.

ORGANIZAÇÃO INTERNACIONAL DO TRABALHO [OIT]. Indigenous and Tribal Peoples Convention, 1989 (No. 169). 1989. Disponível em: https://www. ilo.org/dyn/normlex/en/f?p=NORMLEXPUB:12100:0::NO::P12100_ILO_ CODE:C169\#A6. Acesso em: 20 jan. 2020.

ORLANDI, E. P. Análise de discurso: princípios e procedimentos. Campinas: Pontes, 2003.

RICUPERO, R. A diplomacia na construçáo do Brasil: 1750 - 2016. Rio de Janeiro: Versal Editores, 2017.

SILVA, J. A. da. Parecer. In: CUNHA, M. C. da; BARBOSA, S. (org.). Direitos dos povos indígenas em disputa. São Paulo: Ed. da Unesp, 2018. p. 17-42.

TERENA, M. Povos indígenas e os cidadãos da Selva. In: CARNEIRO, M. L. T.; ROSSI, M. S. (org.). Índios no Brasil: vida, cultura e morte. São Paulo: IHF; LEER/ USP; Intermeios, 2019. p. 17-22.

Recebido em 10 de abril de 2020.

Aprovado em 08 de junho de 2020. 